\title{
Eestikeelset aineõpet mõjutavad tegurid: vene koolijuhtide seisukohti ja strateegiaid
}

\author{
Mare Kitsnik $^{\mathrm{a} 1}$, Helena Metslang ${ }^{\mathrm{b}}$ \\ a Tallinna Ülikooli eesti keele ja kultuuri instituut \\ b Tartu Ülikooli eesti ja üldkeeleteaduse instituut
}

\begin{abstract}
Annotatsioon
Aastatel 2007-2012 läksid vene õppekeelega koolid üle kohustuslikule eestikeelsele aineõppele. Alates 2011. aastast õpivad kõik 10. klassi astuvad noored gümnaasiumis kohustuslikult $60 \%$ aineid eesti keeles, sh riikliku õppekavaga määratud viit ainet. Koolijuhid näevad eestikeelse aineõppe kasu õpilastele ning arendavad muudatuste elluviimise raskusest hoolimata programmi edasi. Artiklis käsitleme juhtide hinnanguid eestikeelset aineõpet mõjutavatele teguritele ning nende strateegiaid eestikeelse aineõppe arendamisel. Toetudes uuringule „Kakskeelne õpe vene õppekeelega koolis" (Metslang et al., 2013), kirjeldame direktorite ja õppejuhatajate peamisi muresid, mis on seotud eestikeelse ainekava rakendamisega muudatuse algusetapil. Kasutame selleks 2012. aasta sügisel kuues koolis korraldatud 12 juhiintervjuu tulemusi. Võrdleme neid 77 tunnivaatluse käigus ning õpilaste ja õpetajate anketeerimise ja fookusrühma intervjuude teel kogutud andmetega. Uuringust selgus, et olulisteks probleemideks on sobivate õpetajate leidmine, gümnaasiumiastujate vähene eesti keele oskus ja keeleõppe motivatsioon ning õpilaste kesised õpioskused. Vaatleme, kas juhid rakendavad strateegiaid nende probleemide lahendamiseks. Artiklis tõuseb esile vajadus suurendada direktorite ja õppejuhatajate teadmisi kakskeelse haridusprogrammi juhtimisest.

Kuna õppeprogrammi järgi algab kohustuslik teiskeelne õpe alles gümnaasiumiastmes, on Eesti mudel maailma kakskeelse hariduse kontekstis haruldane. Levinud mudelite puhul alustavad õpilased teiskeelset õpet nooremas eas: alates lasteaiast, algkoolist või põhikoolist. Artiklis analüüsime Eesti mudeli tulemuslikkust eri programmikomponentide mõju uurimise kaudu.
\end{abstract}

Võtmesõnad: eesti keel, keeleõpe, kakskeelne haridus, lõimitud aine- ja keeleõpe, metoodika, juhtimine

1 Eesti keele ja kultuuri instituut, Tallinna Ülikool, Narva mnt 25, 10120 Tallinn; marekitsnik@gmail.com 


\section{Sissejuhatus}

Kui võrrelda vene õppekeelega koolide eesti keele õpet iseseisvusaja algusega, on näha olulist arengut õppesüsteemis, õppematerjalide ja õpetajakoolituse kvaliteedis ning gümnaasiumilõpetajate keeletasemes. Ôppe paranemisest hoolimata ei näita eesti keele riigieksami tulemused, et koolilõpetajate keeletase oleks nii hea, et tagaks neile eestlastega võrdsed võimalused Eestis kõrgharidust omandada või end Eesti ühiskonnas raskusteta teostada. Ühe sammuna selle olukorra parandamiseks on vene õppekeelega gümnaasiumid läinud üle eestikeelsele aineõppele. Koolid on eestikeelse aineõppe käivitanud ning on muudatustega kohanemas (Metslang et al., 2013). Paljudel koolidel on ka varasem pikemaajaline eestikeelse aineõppe kogemus.

Kuigi vene õppekeelega koolide üleminek eestikeelsele aineõppele sätestati juba 1993. aastal põhikooli- ja gümnaasiumiseaduses ning ettevalmistus ja toetus on olnud märkimisväärne, ei ole muutus olnud kerge ei koolidele ega õpilastele. Siinses artiklis kajastatavas uuringus tuli selgelt esile, et eri huvirühmades kaldutakse üleminekut hindama liiga järsuks ja raskeks. Lahenenud ei ole sobiva õppevara ja kvalifitseeritud õpetajate leidmise probleemid ning eestikeelse aineõppe programmi juhtimises ei ole koolitasandil veel kujunenud süsteemsust. Suure osa põhikoolilõpetajate eesti keele oskus ei ole gümnaasiumiõppeks veel piisav, lisaks on küsitav, kas gümnaasiumide üleminek eestikeelsele aineõppele on toonud kaasa õpilaste keeleoskuse paranemise (Piirimägi et al., 2014). Kakskeelsete õppeprogrammide arendus on aeganõudev ja kulukas - seda näitab ka muude maade kogemus. Eesti olukorda komplitseerib omakorda veel vene õppekeelega koolide õpilaste arvu kiire kahanemine.

Siinse artikli aluseks on 2011. aastal Haridus- ja Teadusministeeriumi tellitud uuring, mille viis läbi Tallinna Ülikooli eesti keele ja kultuuri instituudi töörühm (Metslang et al., 2013). Selle käigus uuriti 2012. aasta sügisel venekeelsetes koolides toimunud eestikeelset aineõpet (ajalugu, eesti kirjandus jm ained) ning eesti keele kui teise keele õpetust mõjutavaid tegureid, rõhuasetusega õpilaste toimetulekul.

\section{Taust}

\section{Lõimitud aine- ja keeleõpe}

Et anda vähemusrühmadesse kuuluvatele õpilastele riigikeeleoskus või kõigile õppuritele kõrgel tasemel kakskeelsus kogu eluks, kasutatakse haridussüsteemides järjest enam kakskeelset õpet. Kakskeelne õpe on laialt 
levinud kogu maailmas ning rohked uuringud kinnitavad, et oma emakeelest erinevas keeles õppimine on tõhus õppeviis, mille kaudu on õpilastel võimalik omandada nii aineteadmised ja -pädevused kui ka heal tasemel teise keele oskus; lisaks arendab kakskeelne õpe õpilastes enesekindlust ja positiivset suhtumist keeleõppesse (Marsh, 2002; Mehisto, 2011; Mehisto, Marsh, Frigols, Võlli, \& Asser, 2010). Kakskeelse õppe metoodikas domineerib lõimitud aine- ja keeleõppe metoodika (LAK-õpe, inglise keeles content and language integrated learning ehk CLIL). Üks kakskeelse hariduse juhtteadlasi on määratlenud LAK-õpet võrdlemisi laialt:

LAK-õpe on lähenemine, kus õppeaineid tervikuna või nende osi õpetatakse võõrkeeles, kusjuures õpetamisel keskendutakse kahele sihile: nii ainesisu omandamisele kui ka samaaegsele võõrkeeleõppele. (Marsh, 1994)

Sellise määratluse puhul kuuluvad LAK-õppe hulka keelekümblus (lasteaiast, algkoolist või põhikoolist algav kindla raamistiku järgi toimiv kakskeelse õppe programm $)^{2}$ ja mitmesugused muud programmid. LAK-õpe hõlmab mitte-keeleainete, nt ajaloo, geograafia õppimist teises keeles või võõrkeeles. Sageli rõhutatakse LAK-õppe kolmanda alustalana õpioskuste arendamist, lisaks tähtsustatakse hea emakeeleoskuse saavutamist, mis mõjutab õpilaste edasijõudmist märkimisväärselt (nt Lindholm-Leary \& Borsato, 2006; Mehisto et al., 2010). Teine kakskeelse hariduse juhtuurija Coyle (2007) on püüdnud määratleda valdkonnaga seotud mõisteid ja on esitanud põhimõtted, mida võiks võtta LAK-õppe uuringute aluseks. Ta toob esile LAK-õppe definitsioonides ja ka praktilises kasutuses esineva suure varieeruvuse (kohustuslikkuse, õppe intensiivsuse, programmi kestuse ning programmiga liitujate vanuse, keeleoskuse jm osas), kuid märgib, et kõigi käsitlusviiside ühisjooneks on püüe integreerida aine- ja keeleõpet. Kuigi LAK-õppele on ette heidetud, et liigne keskendumine keelele seab ohtu kvaliteetse ainealase hariduse andmise, arvab Coyle teisiti:

[Ainete] Lõimingul on pedagoogilise vahendina suur mõju. Selle eesmärk on kaitsta ainet, mida õpetatakse, edendades samal ajal keeleoskust, mis on ühtaegu nii õppimise vahend kui ka õppeprotsessi eesmärk. (Coyle, 2002, lk 27)

Kuigi ideaalis on lõiming sisuline ja süvitsi minev, on seda praktikas raske saavutada. Näiteks leiti 2012. aastal Saksamaal toimunud LAK-õppe

2 Eesti keelekümbluse kohta vt kke.innove.ee. 
spetsialistide kohtumisel, et LAK-õppe rakendamisel ja selle tegeliku lõimingupotentsiaali realiseerimisel on veel palju arenguruumi (Brüning \& Purrmann, 2014). ${ }^{3}$ Coyle (2007) tõstab esile õpetajate kaksikrolli aine- ja keeleõpetajana ning peab seda metoodika rakendamisel üheks sagedasemaks raskuskohaks. Ta meenutab, et tuleb arvesse võtta, et LAK-õppes viivad õpet läbi nii aineõpetajad (ajalugu, geograafia vm), kes ei tunne keeleomandamise teooriat, kui ka keeleõpetajad, kes kipuvad sageli keelendite väljendusrikkust ja vormi üle tähtsustama, arvestamata õppurite tegelikke vajadusi LAK-õppe situatsioonis. Teiskeelse õppe toetamiseks vajalike keelendite valikul on õpetajal vaja analüüsida õpilaste funktsionaalseid, ainesisust, grupitöödest jm ülesandetüüpidest tulenevaid keelekasutusvajadusi, mitte lähtuda keeleõppes tavapärasest teemade järgnevusest (Coyle, 2007).

LAK-õppe protsessis on oluline hoida õiget tasakaalu õppurite keeleoskustaseme ja õppesisu kognitiivse raskuse vahel. Coyle (2007) soovitab vähese keeleoskusega õpilaste õppeprotsessi enam toetada ning aidata neil ainesisuni jõuda lihtsama keele kaudu. Õpilaste kognitiivseks toetamiseks tuleb kasutada mitmekesiseid võimalusi, mis hõlmavad muidki vahendeid peale keele (Coyle, 2007).

Lindholm-Leary ja Borsato laiaulatuslikus teaduskirjanduse uuringus (2006) käsitletakse õpilaste saavutusi ja tulemusi kakskeelse õppe programmides:

[Analüüsitud uuringute seas] Ei olnud ühtki põhikooli- või gümnaasiumiõpilastega tehtud uuringut, mis leidnuks, et kakskeelselt haritud õpilased oleksid vähem edukad kui võrdlusrühma õpilased. Lisaks ilmnes pikiuuringutes, et mida kauem kakskeelses programmis õpitakse, seda positiivsemad on õpitulemused. Kõik see puudutas nii lugemise ja matemaatika õpitulemusi, keskmist hinnet, kohalkäimist, gümnaasiumi lõpetamist kui ka suhtumist endasse ja kooli. (Lindholm-Leary \& Borsato, 2006, lk 201-202; vt ka Mehisto, 2011).

Ka Eesti uuringud on kinnitanud, et teises keeles õppides on õpilaste akadeemiline edukus vähemalt samaväärne või parem kui emakeelses õppes (nt Sau-Ek, Loogma, \& Vainu, 2011; Seepter, 2014). Samas on uuringud näidanud, et kui õpe ei toimu läbimõeldud ja süsteemselt juhitud programmi järgi, ei saavuta paljud õpilased eakohast pädevust ei aines ega keeles (Genesee

3 Freie Universität Berlini ja Humboldt Universität Berlini ekspertide kohtumine novembris 2012 Berliinis. Autorid ei täpsusta, kas ekspertide kogu leidis seda Saksamaal või terves Euroopas toimuva LAK-õppe kohta, kuid on selge, et potentsiaali täielik saavutamine saab olla pigem erand kui reegel igas riigis. 
\& Lindholm-Leary, 2012). Kehvemaid tulemusi on andnud programmid, kus õpilaste emakeele areng on unarusse jäetud, nt USA early-exit-tüüpi ettevalmistusprogrammid, kus püütakse vähemuskeelt kõnelevad õpilased kiirelt ingliskeelsetesse klassidesse üle viia. Samuti on kritiseeritud LAK-õppe vm kakskeelse õppe programme, kus õpilaste mahajäämust on põhjustanud õppemetoodika ja keeletoe andmise puudujäägid või ebapiisav ettevalmistustöö programmi käivitamisel (nt Hongkongi laiaulatusliku programmi ebaõnnestumine peamiselt juhtimisaspektide puudujäkide tõttu) (vt Lindholm-Leary \& Borsato, 2006; Mehisto, 2011).

\section{Haridusjuhtimisest}

Järgnevalt vaatleme lähemalt juhtimise tähtsust kakskeelse õppe tulemuslikkuse parandamisel. Kuna kakskeelne õpe on muu hariduse osa, mõjutavad selle tulemuslikkust peale eriomaste tegurite ka paljud muud tegurid, mis on ühised kogu (üld)haridussüsteemile.

Enamikus Eesti koolides kasutatakse tulemuslikkuse hindamisel Euroopa täiusliku organisatsiooni mudeli EFQM alusel loodud mudelit. Türk jt (2011) jaotavad oma uurimuses selle põhjal tulemuslikku juhtimist mõjutavad tegurid kolmeks: 1) õpiprotsess, sh (eelkõige vaimne) õpikeskkond, 2) õpetajate töösoorituse hindamine ja tulemustasustamine ning 3) kooli finantstulemuslikkus. Õpiprotsessi all käsitletakse üldisemaid küsimusi, milleks on individuaalne lähenemine õpilastele, õpilaste huvidele orienteeritus ja kooliga rahulolu, õpilasi toetav koolikeskkond, kooli koostöö teiste osalistega (eraldi vaadeldakse ka vene õppekeelega koole). Praegune artikkel keskendub samuti õpiprotsessile vene õppekeelega koolides, kuid eritähelepanu on keele- ja aineõppe aspektidel.

Üldhariduskooli juhtimine on kompleksne protsess ning seda on võimalik käsitleda tasandite süsteemina. Türk jt (2011) lähtuvad üldhariduskoolide tulemuslikkuse uurimisel Brudani (2010) organisatsioonitasandite teoreetilisest raamistikust. Nad kirjeldavad eraldi strateegilise juhtimise, operatiivse (operatsioonilise) juhtimise ja indiviidi tasandit, mis kõik mõjutavad kooli tulemuslikkust. Kõrgeim, kooli strateegilise juhtimise tasand hõlmab kooli põhieesmärkide seadmist ja täitmise juhtimist: arengukavaga seotut (sh eksamitulemused ning õpingute jätkamine järgmisel haridustasemel). ${ }^{4}$ Teine tasand, millel ka meie artikkel lühidalt peatub, on operatiivne tasand, kuhu kuuluvad koolisiseste tööplaanide loomine ja rakendamise juhtimine, kooli ja selle huvirühmade igapäevategevuste eesmärgid, tulemuslikkuse

4 Vt eesti keele õppe ja mitmekultuurilisuse aspekte vene õppekeelega koolide arengukavades Klaas-Lang, Praakli, Peedisson, \& Lašmanova, 2014. 
hindamine ning personali, finants- ja sotsiaalset õpikeskkonda ning huvirühmade rahulolu mõõtvad näitajad. Siinne artikkel keskendub aga peamiselt kolmanda, madalaima tasandi küsimustele: indiviidi tasandile ja selle juhtimisele. Indiviidi tasandi alla kuuluvad mudelis näiteks õpetajate töösoorituse mõjutamine, õpetajate hindamise, motiveerimise ja tasustamise süsteem ning keskkonna loomine koostööks, tagasisideks ja kogemuste vahetamiseks (vt Türk et al., 2011).

Türk jt (2011) kirjeldavad ka õpilaste edukuse põhjuste ahelat, kus eri aspektid üksteisest sõltuvad. Nad rõhutavad asjakohaste juhtimismehhanismide mõju:

Õpilaste edukus, sh nende võimalused jätkata õpinguid ja elus väärikalt toime tulla, olenevad suurel määral õpetajatest. Viimaste motivatsioon sõltub ühelt poolt kooli juhtimisest ning teiselt poolt finantsilistest võimalustest. Õpetajate pädevused ja töömotivatsioon sõltuvad organisatsioonist, selle sisekliimast ja kooli juhtimisest, sh eesmärkide seadmisest ja realiseerimisest. Õpetajate töösoorituse hindamine ja vääriline tasustamine tagavad nende motivatsiooni, arengu ja pühendumise. Seda kõike aitab koolis tasakaalus hoida asjakohaselt toimiv sisehindamise süsteem, mille eelduseks on õpetajate ja koolijuhtide eesmärgiline koostöö ja arengut toetav tagasiside. (Türk et al., 2011, lk 21)

Barber ja Mourshed (2007) uurisid PISA võrdlusuuringu, kirjandusuuringu ning ekspertide, otsustajate ja õpetajate arvamuste põhjal 25 maailma edukaima haridussüsteemi edufaktoreid. Nad järeldavad, et kõik vaadeldud süsteemid lähtuvad juhtimises põhimõttest, et parandada saab ainult seda, mida mõõdetakse. Edukate süsteemide juhtimispraktikast toovad nad esile seire ja tõhusa sekkumise, mille kombinatsioonid on eeskujulike õpetamismeetodite järjepideva kasutuse tagamisel kesksed kogu haridussüsteemis (Barber $\&$ Mourshed, 2007). Kahtlemata on seire ja sekkumine olulised ka koolitasandil üksikasjalikumate õppetöö aspektide tulemuslikkuse tagamisel.

\section{Lõimitud aine- ja keeleõppe programmide juhtimine ning programmide tulemuslikkuse tagamine}

On raske eristada tõhusat LAK-õppe juhtimist üldisest heast haridusjuhtimise praktikast. Goldenberg ja Sullivan (1994) analüüsivad kümmet aastat haridusuuendusi USA kakskeelses õppes ning neid käsitlevaid uuringuid. Nad leiavad, et kuigi programmid, mis keskenduvad spetsiaalselt keelele ja kultuurile, on vähemuste hulka kuuluvate õpilaste abistamiseks vajalikud, 
ei ole võimalik ainult selliste programmidega õpilaste edu tagada. Autorid rõhutavad, et vähemuste hariduse tõhustamisel on vajalikeks komponentideks ka efektiivne koolikorraldus, õpetamine ja õppekava. Rahvusvahelises kogemuses on efektiivsete kakskeelse hariduse programmide tunnustena välja toodud näiteks järgmisi jooni (millest paljud kattuvad ka tõhusate ükskeelsete haridusprogrammide tunnustega):

- ühtne laiapõhjaline jagatud visioon ja eesmärgid;

- kakskeelsuse ja mitmekultuurilisuse tähtsustamine õppetöös;

- kõigile õppijatele võrdsete võimaluste tagamine, võttes arvesse individuaalsust;

- suured ootused kõigi õppijate saavutusvõime suhtes;

- ópioskuste ja kriitilise mõtlemise arendamine;

- abi ja nõu kättesaadavus õpetajatele;

- suhtumine vanematesse ja kogukonnaliikmetesse kui koolis oodatud külalistesse, nende juhendamine õpilastele keeletoe andmiseks;

- mõõdikute kasutamine edusammude hindamisel (nt Lindholm-Leary \& Borsato, 2006; Mehisto, 2009, 2011; vt ka Green, 1999).

Barberi ja Moushedi (2007) edukate haridussüsteemide uuringus selgus, et peamised eeldused koolide tulemuslikkuse suurendamisel on:

1) õigete inimeste leidmine õpetajaametisse; 2) tingimuste loomine, et need inimesed kujuneksid headeks õpetajateks-juhendajateks; 3 ) suutlikkus tagada iga õpilase õpetamine parimal võimalikul viisil. (Barber \& Moushed, 2007, lk 2)

Goldenberg ja Sullivan (1994) esitavad hüpoteesi, miks pingutused kakskeelse hariduse arendamisel ei ole USAs hoolimata läbimõeldud lähenemisviisist pikka aega siiski edu toonud, ning korraldavad selle kinnituseks katse. ${ }^{5}$ Hüpoteesi kohaselt peaks kooli kakskeelse õppe programmi edukuse tagama mudel, mis hõlmab osaliste ühist eesmärkide seadmist, edu mõõdikute olemasolu, järjepidevat ja tõhusat õpetajate abistamist-nõustamist ning toetavat ja tagantlükkavat (positiivset survet avaldavat) juhtimist. Hüpotees põhineb oletusel, et suure hulga muutuste ebaedu põhjuste seas, mida uuringutes oldi seni välja pakutud, on olulisimaks pidevuse ja sidususe puudumine programmide rakendamisel. See on aga tingitud koolitöötajate ülekoormatusest (mida on osaliselt ka põhjustanud hariduse sage reformimine) ning

Autorid korraldasid katse aastatel 1990-1994 ühes väga keerukate oludega koolis (peaaegu kogu õpilaskond mitte-inglise emakeelega, asukoht suure vaesuse ja kuritegevuse ning narkoprobleemiga piirkonnas, koolihoone paiknemine otse lennukite maandumisraja all, nii et õppetööd segas ka müra). 
peegeldab sellise koolikonteksti puudumist, kus tuuakse kokku soovitud muudatuse idee ja õpetajate tegelikud tegevused (vt ka Fullan, Bennett, \& Rolheiser-Bennett, 1990). Maailmakogemuses on reformide edukust pärssinud ka muudatuste elluviimiseks esmatähtsate sisuliste ja pedagoogiliste teadmiste puudus (Cohen et al., 1990).

Paljudes uuringutes leitakse, et õpetajate kvaliteet mõjutab õpilaste saavutusi ja üldse haridussüsteemi kvaliteeti tugevalt (vt nt Brüning \& Purrmann, 2014). Eduka LAK-õppe õpetaja tegevust õppetunnis on kirjeldatud mitmeti, oluliseks peetakse näiteks järgmist:

- õpilased saavad aineõppes õpiainest sobival moel (õppematerjal on piisavalt, kuid mitte liiga keeruline, autentne ja atraktiivne);

- keeleõpe toimub teiskeelse ainesisu läbitöötamisel;

- õpetajad aitavad lihvida ka õpilaste keelelist väljendust, kontrollides arusaamist, küsides selgitusi ja tuues näiteid;

- ópetajad pakuvad õpilastele rikkalikke võimalusi ise keelt kasutada (võimalus reageerida, erinevad interaktiivsed tööformaadid, kommunikatiivselt jõukohased ülesanded jne);

- õpetajad õpetavad õpilastele strateegiaid, kuidas kompenseerida keelenditest mittearusaamist jm (Graaff, Koopman, Anikina, \& Westhoff, 2007; vt ka Cummins, 2000; Navés, 2009).

LAK-õppe õpetajate kompetentsuse kohta on koostatud erinevaid raamistikke ja mudeleid (Bertaux, Coonan, Frigols-Martín, \& Mehisto, 2010; EUCLID, 2011; Marsh, Mehisto, Wolff, \& Frigols, 2011; vt ka Brüning \& Purrmann, 2014). Eesti koolide õpetajate tegevust analüüsides on murekohana välja toodud, et õpetajad peavad oma õpilaste võimeid väga kasinateks ning seostavad vajakajäämisi enda tegevustes õpilaste vähese võimekusega (Loogma, Ruus, Talts, \& Poom-Valickis, 2009).

\section{Õpilaste motivatsioon kui oluline lõimitud aine- ja keeleõppe tulemuslikkuse mõjur}

Õpilaste valmisolek nii teise keele õppeks kui ka teiskeelseks aineõppeks ning seeläbi õppe tulemuslikkus sõltuvad paljuski nende motiveeritusest. Õpimotivatsioon on keeruline nähtus, mille kirjeldamiseks on uurijad loonud mitmeid mudeleid (nt Dörnyei, 1994; Gardner, 2007; Williams \& Burden, 1997). Tunnustatud motivatsiooniuurija Gardneri mudelis (2007) on näidatud, et teise keele õppe motivatsioon kujuneb peamiselt kahte tüüpi kontekstis: kultuuri- ja hariduskontekstis. Kultuurikontekst hõlmab teise keele õppimise väärtuslikkust õppijate silmis (kuivõrd õppijad tunnevad, et teist keelt on nende elus vaja ja kuidas ühiskonnas teise keele oskust 
hinnatakse) ja õppija usku sellesse, et tal on võimalik teine keel omandada. Seega kuuluvad siia kooli poolt rohkem või vähem mõjutatavad aspektid. Hariduskontekst hõlmab tegureid, mida koolijuht saab otseselt mõjutada: üldist õppekorraldust, õppekava, õpetaja käitumist ja suhtumist, õppesisu, õppematerjale, õppetegevusi ning õpikeskkonda (õpperuumi, õpperühma) (Brophy, 2004; Dörnyei, 2001). Motivatsiooni toetamiseks on seega vaja aidata õpilastel näha teise keele õppimise vajalikkust ja sisendada usku, et kõik saavad keele omandamisega hakkama. Samuti on väga vajalik, et õpilased tajuksid käsitletavaid teemasid ja õppetegevusi enda jaoks tähenduslikena, et need oleksid jõukohased ning nende tegemisel pakutaks vajalikku tuge. Õppetegevuste ja -sisuga seoses aitavad õpimotivatsiooni suurendada aktiivõppe meetodid jm LAK-õppes kasutatavad meetodid, mis võimaldavad õpilastel ise mõelda ja tegutseda ning õppimisest rõõmu tunda (Kitsnik, 2014; Mehisto et al., 2010).

\section{Metoodika ja valim}

Uuringu põhivalim sisaldas kaheksat kooli, kus viidi täismahus läbi kõik uuringu tegevused. Nende seas oli neli Tallinna kooli, kolm Ida-Virumaa kooli ning üks muu Eesti kool. Valim peegeldas seega vene õppekeelega koolide regionaalset ja arvulist jaotust. Esindatud oli kaks varase ja kaks hilise keelekümblusega kooli, kus uurisime nii keelekümblustaustaga kui ka ilma selleta õpilaste kogemust. Andmete kogumine hõlmas peale põhietapi (2012. aasta septembris-oktoobris) ka eri tüüpi küsimustike katsetamist kahes Tallinna koolis (kevad 2012) - need koolid ei kuulunud põhivalimisse.

Artiklis kõrvutame eri andmekogumismeetodite abil saadud tulemusi. Nii kvantitatiivse kui ka kvalitatiivse metoodika kaasamine uurimusse võimaldas sageli vastukäivaid andmeid kriitiliselt analüüsida. Artikli aluseks oleva uuringu ettevalmistus hõlmas koolide valimi koostamist, konsulteerimist LAK-õppe ekspertidega (Peeter Mehisto ja Kai Võlli), küsimustike, intervjuuraamide ja tunnivaatluslehtede loomist, katsetamist ja täiendamist, õpetajate anketeerimist, koolikülastusi, fookusrühma intervjuude tegemist, intervjuude litereerimist, ankeetide sisestamist ning andmeanalüüsi.

Siinses artiklis on kõige olulisemaks uuringutegevuseks intervjuud koolidirektorite ja õppejuhatajatega. Kõik 12 intervjueeritud koolijuhti (sh kaks katseuuringus osalenud koolijuhti) omavad üle 15 aasta pikkust õpetajatöö kogemust. Koolijuhina töötamise staaži on kolmel intervjueeritaval rohkem kui 16 aastat, neljal 6-10, kahel 3-5 ja kolmel 1-2 aastat. Nelja juhi emakeel on eesti keel, seitsmel juhil vene ning ühel juhil nii eesti kui ka vene keel. 
Kõik koolijuhid on kaks- või mitmekeelsed. Kuus juhti 12-st on ise õppinud ja/või õpetanud võõrkeeles. Üheksa juhti 12-st on lõpetanud ülikoolis filoloogia eriala, kuuel koolijuhil on eesti keele kui teise keele või võõrkeele õpetaja kutse. Tabel 1 annab ülevaate muudest andmetest, mida on siinse artikli juures lisaks arvesse võetud.

Tabel 1. Uuringu käigus kogutud andmete maht (intervjuud ja ankeedid)

\begin{tabular}{l|l|c|c|c|c}
\hline Meetod & \multicolumn{1}{|c|}{ Ühik } & $\begin{array}{c}\text { Kooli- } \\
\text { juhid }\end{array}$ & Õpilased & $\begin{array}{c}\text { Eestikeelse } \\
\text { aine } \\
\text { opetajad }\end{array}$ & $\begin{array}{c}\text { Eesti keele } \\
\text { kui teise keele } \\
\text { ópetajad }\end{array}$ \\
\hline $\begin{array}{l}\text { Individuaal- } \\
\text { intervjuud (sh } \\
\text { katseuuring) }\end{array}$ & $\begin{array}{l}\text { Intervjueeritavate } \\
\text { arv }\end{array}$ & 12 & & & \\
\hline Ankeedid & Vastajate arv & & 561 & 180 & 118 \\
\hline $\begin{array}{l}\text { Fookusrühma } \\
\text { intervjuud (sh } \\
\text { katseuuring) }\end{array}$ & $\begin{array}{l}\text { Intervjuude arv / } \\
\text { osalejate arv }\end{array}$ & & $4 / 22$ & $5 / 19$ & $4 / 20$ \\
\hline
\end{tabular}

Eesti keele tundide ja eestikeelsete ainetundide vaatlused toimusid 9.-12. klassides. Keeletunnivaatlustest (kokku 37) toimus kolm keelekümblustaustaga klassides ja ülejäänud tavaklassides. Ainetunnivaatlustest (kokku 40) olid kolm tundi varase keelekümbluse taustaga klassis, kuus hilise keelekümbluse taustaga klassis ja 31 tavaklassis. Põhivalimikoolidele lisaks anketeeriti eesti keele kui teise keele õpetajaid ning eesti keeles aineid õpetavaid õpetajaid vene õppekeelega koolides üle Eesti: elektroonilised ankeedid keele- ja aineõpetajatele saadeti 56 kooli. Uuringutegevusi on lähemalt kirjeldatud aruandes (Metslang et al., 2013).

Intervjuuküsimustike koostamisel, tundide vaatlemisel ning kogutud andmete tõlgendamisel võtsime võrdlusaluseks LAK-õppe käsiraamatus (Mehisto et al., 2010) ning muus metoodikakirjanduses (nt Krall, Sõrmus, \& Toomsalu, 1997; Nunan, 2004; Willis, 1996, 2008) esitatud põhimõtted. Osa järgnevates jaotistes esitatud seisukohti põhineb ka autorite praktikukogemusel keeleõpetaja ja -õppejõuna ning õppematerjalide autorina. 


\section{Tulemused}

\section{Koolijuhtide hinnangud õpilaste eestikeelseks aineõppeks valmisolekule ja strateegiad selle suurendamiseks}

Kõik koolijuhid peavad eestikeelset aineõpet gümnaasiumis üldiselt positiivseks muutuseks ning näevad selle potentsiaalset kasu õppijate jaoks. Eestikeelse aineõppe peamise kasuna nimetavad juhid õpilaste eesti keele oskuse paranemist, mis omakorda tagab parema toimetuleku Eesti ühiskonnas - nii kõrgkoolis kui ka töökohtadel. Juhid arvavad, et eestikeelne aineõpe pakub õpilastele reaalset keelekeskkonda ja sunnib neid eesti keeles suhtlema. Samuti leiavad juhid, et eestikeelse aineõppe tulemusena paranevad eesti keele riigieksami tulemused. Samas on koolijuhid seisukohal, et suur osa õpilastest ei ole gümnaasiumi eestikeelseks aineõppeks valmis. Juhtide hinnangul mõjutavad õpilaste valmisolekut kolm peamist tegurit: eesti keele oskuse tase põhikooli lõpus, õpimotivatsioon ja õpioskuste olemasolu.

\section{Eesti keele oskuse tase põhikooli lõpus}

Üheks võtmeküsimuseks õpilaste eestikeelse aineõppega toimetulekul peavad koolijuhid põhikooli lõpuks saavutatavat keeleoskust. Riikliku ainekava kohaselt on põhikooli lõpuks seatud eesmärk saavutada keeleoskustase B1 ehk iseseisva keelekasutaja madalam tase. Sellise keeleoskusega inimene tuleb toime iseseisva suhtlemisega ühiskonnas, mõistab kõike olulist endale tuttaval teemal (töö, kodu, kool, vaba aeg), oskab koostada lihtsat teksti tuttaval või endale huvipakkuval teemal, kirjeldada sündmusi, kogemusi, unistusi ja eesmärke ning lühidalt põhjendada ja selgitada oma eesmärke ja plaane. ${ }^{6}$ Rohkem kui pooled küsitletud koolijuhtidest on arvamusel, et sellisest keeleoskusest ei piisa keerukamate akadeemilise keele kesksete ainete (nt geograafia, ajaloo, ühiskonnaõpetuse) õppimiseks gümnaasiumitasemel. Seetõttu nõuab eestikeelne aineõpe ka tugevamatelt õpilastelt suurt pingutust. Ka õpilased näevad olukorda probleemsena. Üle $40 \%$ õpilasankeedile vastanutest ei saa / pigem ei saa oma sõnul keerukamate ainete tundides toimuvast aru. Õpilasankeetides enam nimetatud eestikeelsetest õppeainetest arusaamist kajastab tabel 2.

6 „Euroopa keeleõppe raamdokument”, skaalatabel „EN ühtsed keeleoskustasemed. Üldskaala” (2007). 
Tabel 2. Eestikeelsest õppeainest/kursusest arusaamine (õpilaste ankeetküsitluse tulemusi)

\begin{tabular}{l|c|c|c}
\hline Aine & $\begin{array}{c}\text { Sellele küsimusele vastajad, } \\
\text { kes olid ainet eesti keeles } \\
\text { oppinud }(\boldsymbol{n}=\mathbf{5 5 0})\end{array}$ & $\begin{array}{c}\text { Hea / } \\
\text { pigem hea } \\
\text { arusaamine \% }\end{array}$ & $\begin{array}{c}\text { Halb / } \\
\text { pigem halb } \\
\text { arusaamine \% }\end{array}$ \\
\hline Kehaline kasvatus & 303 & 88 & 12 \\
\hline Muusikaõpetus & 539 & 80 & 20 \\
\hline Kunstiõpetus & 336 & 74 & 26 \\
\hline Inimeseõpetus & 297 & 72 & 28 \\
\hline Eesti kirjandus & 528 & 67 & 33 \\
\hline Ühiskonnaõpetus & 479 & 61 & 39 \\
\hline Ajalugu & 489 & 57 & 43 \\
\hline Geograafia & 446 & 56 & 44 \\
\hline Bioloogia & 242 & 56 & 44 \\
\hline
\end{tabular}

Paremini on eestikeelseks aineõppeks koolijuhtide hinnangul valmis keelekümblusklassides õppinud noored ja need õppurid, kes on juba põhikoolis õppinud mõnd ainet eesti keeles. Keelekümbluse esmatähtsat mõju põhikoolilõpu eesti keele kui teise keele eksami tulemustele kinnitab ka keelekümbluse mõju uuring (Sau-Ek et al., 2011).

Suurem osa siinses uuringus intervjueeritud koolijuhte arvab, et eestikeelse aineõppe tõttu kannatavad gümnaasiumiõpilaste aineteadmised. Koolijuhtide arvamust jagavad ka eesti keeles õpetavad aineõpetajad, kellest $84 \%$ hinnangul on tugevamal poolel klassist eesti keele oskus eesti keeles õppimiseks pigem või kindlasti piisav. Samas arvab ainult 22\% vastanuist sedasama klassi nõrgema poole kohta. Õpetajate üksmeelsel hinnangul kannatab seetõttu õpetamise kvaliteet - jõutakse läbi võtta vähem materjali ja selle mõistmine jääb pealiskaudsemaks. Koolijuhtide hinnangul on vajalik tõsta põhikoolilõpetajate keeleoskuse taset praeguselt B1-tasemelt B2-tasemele ehk iseseisva keelekasutaja kõrgemale tasemele. Juhtide arvates peaks sellise taseme saavutamine põhikooli lõpuks olema ka võimalik. Samal seisukohal on ka eesti keeles õpetavad aineõpetajad, kuid eesti keele õpetajad jäävad eriarvamusele - ankeedile vastanud ei pea B2-taset põhikooli lõpuks reaalseks eesmärgiks, kuigi keeletundide arv on juba praegu väga suur.

Hoolimata oma kindlast usust põhikooli kõrgema keeleõppe-eesmärgi seadmise vajalikkusse, ei esita enamik intervjueeritud koolijuhte mingeid strateegiaid eesti keele kui teise keele tundides toimuva õppe arendamise kohta. Ainult kaks juhti arvab, et parema eesti keele oskuse saavutamiseks 
on vaja teha muudatusi eesti keele kui teise keele õpetamises. Sealhulgas toob üks koolijuht esile selge vajaduse teha pöördelisi muudatusi eesti keele õpetamise metoodikas ja muuta õpetajate hoiakuid ainekava läbimise ning eksamiks valmistumise suhtes. Kaks koolijuhti (paremate eksamitulemustega koolidest) plaanivad tõhustada eesti keele õpetust nii põhikoolis kui ka gümnaasiumis eesti keele tundide lisamisega õppekavasse. Ühes koolis plaanitakse lisada põhikooliastmesse selliseid eesti keele tunde, kus õpetataks eestikeelseteks ainetundideks vajalikku sõnavara. Keeleoskuse parandamiseks põhikoolis on kõigi küsitletud koolijuhtide arvates vaja ka alustada eesti keeles ainete õppimist esimeses ja teises kooliastmes. Juhtide sõnul peaks seejuures alustama kergematest ainetest ning liikuma sujuvalt keerukamate juurde. Reaalained (matemaatika, keemia ja füüsika) peaksid kõigi koolijuhtide arvates jääma emakeelseks, vähemalt senini, kuni pole ette valmistatud pädevaid õpetajaid ja kvaliteetseid õppematerjale. Mõnes uuritud koolis on eestikeelset aineõpetust põhikooli tasandil juba ka rakendatud. Kuna keelekümblusklassid on end juhtide silmis igati õigustanud ja lapsevanemad tunnevad kasvavat huvi oma laste õppimise vastu nendes klassides, plaanivad koolijuhid keelekümblusklasse tulevikus rohkem avada.

\section{Keeleõppe motivatsioon}

Koolijuhid peavad motivatsiooni üheks keeleõppe edukuse ja teiskeelse aineõppega toimetuleku põhieelduseks. Juhtide hinnangul on aga üleminek $60 \%$ eestikeelsele aineõppele olnud oluliseks õpilaste eesti keele õppe motivatsiooni vähendajaks. Õpilaste ebapiisavat õpimotivatsiooni nimetasid probleemina rohkem kui pooled intervjueeritud koolijuhid. Osa juhte leiab, et õpilaste motivatsiooni puudumine on tingitud laiematest ühiskonnaprobleemidest - see tähendab Gardeneri mudeli kultuurikonteksti teguritest, mida ei saa koolijuht mõjutada (vt eespool). Paljud õpilased ei seosta juhtide sõnul enda tulevikku Eestiga. Õpilaste ankeetküsitluse vastused kinnitavad juhtide arvamust: $49 \%$ õpilastest seostab oma elu Eestiga, 47\% soovib aga minna välismaale õppima või töötama.

Juhid kinnitavad, et teiskeelse õppe raskus on tekitanud hirme nii õpilastes kui ka õpetajates. Sama probleem tuleb esile ka õpilaste fookusrühmades, milles domineerib seisukoht, et eestikeelsed tunnid on liiga rasked, ning väljendatakse muret eksamitega toimetuleku ja edasiõppimise pärast. Juhtide hinnangul ei sobi osa aineid, mille õpetamine eesti keeles on riiklikult kohustuslik, teiskeelseks õppeks oma liigse keerukuse tõttu. Nende arvates sobiksid eesti keeles õppimiseks pigem mittekeelekesksed ained (kehaline kasvatus, kunstiõpetus, muusikaõpetus) ning eestikesksed ained (eesti kirjandus, eesti kultuurilugu). Juhid hindavad siiski, et õpilaste suhtumine 
eestikeelsesse aineõppesse on mõnevõrra paranenud, õpilased on saanud teadlikumaks eestikeelse õppe programmi eesmärkidest ja potentsiaalsetest raskustest ning nende hirmud on võrreldes varasemate aastatega vähenenud.

Aineõpetajate arvamused toetavad juhtide hinnangut eestikeelse aineõppe edukuse ja õpilaste õpimotivatsiooni tugeva seose kohta. Otsest vastuseisu eesti keeles õppimisele aineõpetajad ei tunneta, kuid paljud õpilased on õpetajate arvates väga passiivsed ja eelistavad õppida vene keeles. Pooled uuringus osalenud aineõpetajatest leiavad siiski, et nende õpilased usuvad eestikeelse aineõppe teel saavutatavate heade õpitulemuste võimalikkusesse. Seda arvamust kinnitab ka 60\% õpilaste ankeedivastus eestikeelse aineõppe mõttekusse uskumise kohta. Ülejäänud õpilased aga ei nõustu väitega „Usun, et eestikeelset aineõpet on võimalik nii läbi viia, et omandan aineteadmisi ja mu keel areneb". Eesti keele õpetajadki jagavad koolijuhtide arvamust paljude õpilaste vähese keeleõppemotivatsiooni kohta. Seejuures on artikli autorite hinnangul eesti keele õpetajate seas valdav oma rolli alahindamine õpilaste motivatsiooni kujundamisel.

Koolijuhtide intervjuudes ei tule esile palju õppetööga seotud juhtimistegevusi, mis oleks otseselt suunatud ópilaste keeleõppemotivatsiooni suurendamisele. Mõned koolijuhid mainivad oma katseid leida kooli rohkem empaatilisi ja hea õpetamisoskusega õpetajaid.

Peale otseselt õppetundides toimuva saab eestikeelset aineõpet toetada ja õpimotivatsiooni mõjutada ka mitmete muude tegevuste kaudu. Koolijuhid nimetavad intervjuudes korduvalt tööd lapsevanematega ning klassivälise oppe korraldamist. Koolijuhid usuvad, et lapsevanem paneb aluse lapse suhtumisele eesti keelde, eestikeelsesse aineõppesse ja eestlastesse. Rohkem kui pooled juhid on arvamusel, et järjepidev selgitustöö ning positiivsete tulemuste näitamine on parandanud lapsevanemate suhtumist eestikeelsesse aineõppesse.

Üle poole koolijuhtidest rõhutab klassivälise õppe olulisust ning toob sellekohaste võimalustena näiteid õpilasvahetusest ja muudest ühisprojektidest eestikeelsete partnerkoolidega. Juhid kinnitavad, et on kasutanud ja kavatsevad ka edaspidi kasutada kõiki eelnimetatud klassivälise õppe võimalusi, kuid kolm juhti toovad esile ka probleemi partnerkoolide leidmisega eestikeelsete koolide vähese huvipuuduse tõttu. Aineõpetajate ankeeditulemused kinnitavad koolijuhtide panustamist klassivälisesse õppesse: 90\% neist arvab, et juhtkond toetab õppeprojekte ja tunnivälise õppe üritusi, ning $84 \%$ arvates aitab juhtkond luua võimalusi eesti keele kõnelejatega suhtlemiseks. Samas näitavad õpilaste ankeetküsitluse tulemused, et klassivälist tegevust ehk täpsemalt projekte keelekeskkonnas, eestikeelseid tunnikülalisi, muid kontakte eestlastega, ekskursioone jm klassivälist tegevust on koolides siiski pigem vähe. 


\section{Õpioskused}

Õpilaste eestikeelse aineõppe tulemuslikkust mõjutava olulise tegurina nimetavad koolijuhid õpilaste õpioskusi. Juhid leiavad, et iseseisva õppimise ja selleks vajalike õpioskuste teema on viimastel aastatel eriti teravalt esile tõusnud, sest eestikeelse aineõppega edukaks toimetulekuks ei piisa ainult tunnis osalemisest, vaid palju tööd on vaja teha ka kodus. Juhid tunnevad muret, et paljud noored ei oska õpieesmärke seada ega valda infootsimise oskusi, ei ole harjunud iseseisvalt õppima ega tunne vastutust oma õpitulemuste eest. Ka aineõpetajad jagavad juhtide arvamusi ning leiavad, et paremate õpioskustega õpilased saavad eestikeelse aineõppega kergemini hakkama, nõrgemate õpioskustega noortele käib aine mõistmine ja uue sõnavaraga toimetulek sageli üle jõu.

Juhtide arvates peaksid õpetajad rohkem tegelema õpilaste õpioskuste arendamisega (eesmärkide seadmine, kokkuvõtete tegemine, eneseanalüüs jpm). Nii aine- kui ka keeletundide vaatluste käigus on sellealaseid tegevusi väga vähe näha. Näiteks arendatakse õpioskusi 6-19\% vaadeldud keeletundidest (olenevalt tegevusest). Koolijuhid ei too kordagi välja strateegiaid õpilaste õpioskuste arendamise suunamiseks ülekoolilisel tasandil.

\section{Koolijuhtide hinnangud õpetajate ja õppemetoodika mõju kohta eestikeelsele aineõppele ning strateegiad õpetajate ja õppemetoodika arendamiseks}

\section{Eestikeelsed ainetunnid}

Kõik uuringus osalenud juhid kinnitavad, et on suutnud tagada ainetundide eestikeelsuse. Eestikeelse aineõppe õnnestumise üheks olulisimaks teguriks peavad nad kvalifitseeritud ja sobivate isiksuseomadustega aineõpetajate olemasolu. Juhid tunnevad heameelt empaatilise isiksuse ja kaasahaarava õpetamisstiiliga õpetajate üle, kes suudavad eestikeelse aineõppe õpilastele meeldivaks ja tõhusaks muuta. Samas tunnetavad juhid selliste õpetajate puudust, mainivad korduvalt pidevat muret kõigi õpetajakohtade täitmise pärast ja kirjeldavad juhuseid, kus on tulnud tööle võtta ka ilma ettenähtud keele- ja metoodikaoskusteta õpetajaid. Eriti suur on juhtide sõnul kvalifitseeritud geograafia- ja ajalooõpetajate puudus. Põhiliste arenguvajadustena näevad juhid õpetajate keeleoskust ja metoodika valdamist. Osa juhte mainib, et mitmed õpetajad valdavad küll oma ainet suurepäraselt, kuid puudu jääb oskusest seda õpilastele huvitaval viisil õpetada.

Tunnivaatlused ja aineõpetajate ankeetküsitluse vastused kinnitavad juhiintervjuude tulemusi. Neli viiendikku ankeedile vastanud aineõpetajatest märgib, et nende tunnid on vähemalt kahe kolmandiku ulatuses 
eesti keeles, ja sama hinnangu annavad oma ankeedivastustes ka õpilased. Tunnivaatlused näitavad veelgi suuremat eesti keele kasutamise osakaalu, kuid selle põhjuseks võib vähemalt osaliselt pidada ka vaatleja viibimist tunnis. Õpetajate keeleoskus võib siiski piirata vabamate tunnitegevuste (diskussioonide, rollimängude jmt) korraldamist. Näiteks toovad Tallinna fookusrühmas osalenud õpilased probleemina esile mitmete õpetajate nõrga keeleoskuse, mis raskendab õppimist.

Metoodikaga seoses on enamik juhte teadlikud vajadusest kasutada teiskeelses ainetunnis spetsiaalset õpetamismetoodikat. Intervjuude põhjal võib aga järeldada, et osa koolijuhte ei oma täpset ettekujutust LAK-metoodika põhimõtetest. Näiteks arvab osa juhtidest, et aineõpetaja ülesanne on anda õpilastele edasi aineteadmisi, kuid mitte õpetada keelt, mis on aga selges vastuolus LAK-õppe põhimõtetega. Suurem osa juhte on siiski seisukohal, et aineõpetaja ülesanne on õpetada nii ainet kui ka keelt. Seejuures on juhtide arvates probleemiks paljude aineõpetajate ebapiisav oskus keeleaspektidele tähelepanu pöörata.

Tunnivaatlustes ilmneb, et LAK-õppe metoodikat ei kasutata eestikeelsetes ainetundides süsteemselt. Domineerivad traditsioonilised õppemeetodid (õpetaja loeng, õpetaja juhitud diskussioon terves klassis, konspekteerimine). Aktiivõppe meetodite puhul ilmneb suur vastuolu õpetajate hinnangute ning tunnivaatluste ja õpilaste arvamuste vahel. Õpetajad kasutavad enda sõnul üldiselt aktiivõppe meetodeid tunduvalt rohkem, kui näitavad tunnivaatleja tähelepanekud ja õpilaste hinnangud. Samuti on tundides vähe näha õpilaste jaoks tähendusrikaste teemade käsitlemist ning autentsete ülesannete täitmist. Vaatlustes ilmneb ka aineõpetajate ebapiisav pädevus õpetada peale aine ka keelt. Keeletoe andmine on sageli ebapiisav ning keeleliste osaoskuste harjutamine vähene ja juhusliku iseloomuga.

Koolijuhid toetavad oma sõnul igati õpetajate koolitamist ning positiivse poole pealt toovad juhid välja õpetajate suure valmisoleku ennast täiendada. Samas selgub uuringus, et 36\% ankeedile vastajatest ei ole osalenud teises keeles õpetamise metoodika koolitusel ja $30 \%$ on osalenud koolitusel vaid 1-8 päeva. LAK-õppe koolitust ei ole läbinud ka kõik koolijuhid.

Kvalifitseeritud õpetajate kõrval peavad koolijuhid väga oluliseks LAKõppe edukuse tingimuseks ka kvaliteetsete õppematerjalide olemasolu ja näevad siin mitmeid kitsaskohti. Juhtide meelest on probleemideks üldine kvaliteetsete õppematerjalide puudus ning olemasolevate õppematerjalide sobimatus teiskeelseks õppeks. Sama muret väljendavad ka aineõpetajad, kellest vaid $44 \%$ on õpikutega rahul või pigem rahul. Õpetajate arvates on õpikud liiga teoreetilised ja rasked ning sobivad vaid neile, kes oskavad eesti keelt hästi. Samal meelel on ka õpilased, kelle sõnul on õpikud üks 
peapõhjusi, miks nende aineteadmised kannatavad. Osa juhtidest toob välja, et suur osa aineõpetajaid peab tegema õppematerjale ise, kuid see vähendab sageli õpetamise süsteemsust. Aineõpetajad kinnitavad juhtide arvamust ja väidavad, et on sunnitud liiga palju aega kulutama õppematerjalide otsimisele ja valmistamisele. Tunnivaatlustes oli näha, et õpetajad kasutavad üldjuhul kokkuvõtteid eesti kooli õpikutest (tehes sageli slaidiesitlusi) või kombineerivad internetist saadud materjale. Kvalifitseeritud õpetajate ja õppematerjalide olukorra parandamiseks ootavad koolijuhid abi riigilt.

\section{Eesti keele tunnid}

Eesti keele kui teise keele tundide kohta avaldavad koolijuhid intervjuudes väga vähe arvamust. Kuigi kõik juhid rõhutavad gümnaasiumi eestikeelset aineõpet takistava tegurina õpilaste nõrka eesti keele oskust, ei too nad üldjuhul välja seost eesti keele tundide kvaliteedi ja õpilaste keeleoskustaseme vahel. Paar juhti nimetavad vajadust muuta eesti keele kui teise keele tundides kasutatav metoodika tänapäevasemaks ning paar juhti väljendavad rahulolematust olemasolevate eesti keele kui teise keele õppematerjalidega. Eesti keele kui teise keele õpetamise puudusena näevad juhid liigset keskendumist eksamile.

Samas näitavad uuringu teised osad (õpilaste ja eesti keele kui teise keele õpetajate anketeerimine ja fookusrühmad ning tunnivaatlused), et eesti keele kui teise keele tundidel on väga palju arenguruumi. 52\% õpilaste hinnangul ei ole eesti keele tunnid huvitavad ja 55\% arvates ei seostu eesti keele tunnis õpitu nende koolivälise eluga. Tunnivaatlustes selgub, et õppetegevuste puhul on suur vastuolu õpetajate endi arvamuse ja tunnivaatleja tähelepanekute vahel. Kuigi õpetajad õpetavad enda sõnul tasakaalustatult kõiki keelelisi osaoskusi ning grammatikat ja sõnavara, siis tunnivaatlused näitavad väga ebaühtlast osaoskuste arendamist, ebatõhusat aktiivõppe meetodite rakendamist ning kommunikatiivset keeleoskust mittetoetavat sõnavara- ja grammatikaõpetust. Vaatlustest ilmneb, et eesti keele tundides ei ole peaaegu üldse näha ka teadlikku akadeemilise keele ja ainekeele õpetamist, mis toetaks eestikeelset aineõpet.

Eesti keele õpetajad tunnevad suurt vajadust koolituste järele (hoolimata suurest hulgast läbitud koolitustest) ja soovivad paremaid (süsteemsemaid, tänapäevasemaid) õppematerjale. Koolijuhtidega tehtud intervjuudes eesti keele kui teise keele õppemetoodika ja õppematerjalide arendamise täpsemaid strateegiaid ei arutatud. 


\section{Kokkuvõte ja järeldused}

Uuringust ilmneb, et koolijuhid on suutnud eestikeelse aineõppe käivitada ja seejuures leidnud eesti keeles õpetavad õpetajad. Kõik koolijuhid suhtuvad eestikeelsesse aineõppesse üldiselt positiivselt, nähes selle potentsiaali õpilaste ettevalmistamisel eesti ühiskonnas edukalt toimetulekuks. See hoiak on võtmetähtsusega, sest just koolijuhtidest sõltub suurel määral eestikeelse aineõppe edukus. Samas ei ole juhid gümnaasiumi $60 \%$ eestikeelse aineõppe suhtes sama positiivselt meelestatud ja näevad selles mudelis mitmeid kiiret lahendamist vajavaid probleeme: põhikoolilõpetajate eesti keele oskuse ebapiisavat taset, paljude õpilaste väikest õpimotivatsiooni ning puudulikke õpioskusi, kvalifitseeritud aineõpetajate vähesust ning kvaliteetsete teiskeelseks aineõppeks sobivate õppematerjalide puudumist.

Rääkides teiskeelse õppe programmi juhtimisest ja toetamisest, kirjeldavad intervjueeritud koolijuhid enamasti paindlikku jooksvat reageerimist olukorra vajadustele. Intervjuudes ei maini juhid aga selliseid juhtimistegevusi nagu LAK-õppe kavandamine kooli arengukavas või LAK-õppe arenduse tööplaani koostamine. Juhtidel puudub täpne ettekujutus LAKõppe metoodika sisust ja rakendamiseks vajalikest tegevustest, samuti ei ole hästi välja töötatud strateegia ja tegevusplaan õpetajate arendamiseks selles valdkonnas. Juhtkond ei tegele õpetajate koolitusvajaduse planeerimisega ning eriti oleks vaja jälgida, mil määral jõuab koolitusel õpitu tundidesse. Samuti tegeldakse veel vähe ja ebatõhusalt õpetajate koostöö korraldamise ja suunamisega - nii õpetajate endi vahel kui ka teiste osalistega.

Koolijuhid ei ole piisavalt teadvustanud eesti keele kui teise keele tundide tõhususe ja motiveerivuse tegureid ning nende juhtimise võimalusi. Seetõttu ei oska nad jälgida ega nõuda kvaliteetset metoodikat ega keeletundide tuge eestikeelsele aineõppele (viimane on ka sõltuvuses riiklikest nõuetest: riiklik õppekava ei nõua eesti keele tundides akadeemilise keele õpetamist).

LAK-õppe programmi edu sõltub suurest rühmast omavahel seotud osalistest ja aspektidest. Seetõttu on kindlasti vajalik ka kõigi sidusrühmade koostöös loodud koolitasandi eestikeelse õppe programmi rakenduskava, kus osaliste vahel lepitakse kokku kõik programmi komponendid (sidusrühmad, tegevused, ressursid-materjalid, mõju mõõtmine jne). Asjakohane näide on Eesti keelekümblusprogrammi väljatöötamisel ühistööna loodud lühike tulemuspõhise juhtimise raamistik (vt Mehisto, 2011). LAK-õppe arengule koolis aitab kaasa tulemusjuhtimise põhimõtete keskendamine just sellele valdkonnale. Seetõttu peaks rakenduskava olema töödokumendiks igapäevasel tegevuste kavandamisel, elluviimisel ja hindamisel (vt Türk et al., 2011). Nii aineõpetajate kui ka eesti keele õpetajate taseme- 
ja täienduskoolituse ning õppematerjalide süsteemsemaks arendamiseks vajavad koolijuhid kindlasti ka tõhusat riigipoolset tuge.

Siinse artikli piiranguks on informantide väike arv. Tänu tasakaalustatud valimile annavad artikli aluseks olnud intervjuud siiski põhjust oletada, et süsteemne lähenemine LAK-õppe juhtimisele on veel enamikus venekeelsetes koolides algusjärgus. Intervjuudes ei pandud eraldi rõhku kõrgema tasandi juhtimismehhanismidele - LAK-õppe ja keeleõppe käsitlemisele strateegiates ja töökavades -, mille analüüs aitaks saada tervikülevaate juhtide käes olevatest hoobadest.

\section{Tänusõnad}

Artikli aluseks oleva uuringu töörühma kuulusid peale artikli autorite ka Triin Kibar, Jevgenia Koržel, Ingrid Krall ja Anastassia Zabrodskaja, kes kõik osalesid ka koolijuhte käsitleva uuringuosa ettevalmistamisel. Juhiintervjuude kavandamisel, läbiviimisel ja analüüsimisel ning uurimistulemuste kirjeldamisel oli kandev roll Triin Kibaril. Osa intervjuusid tegi ka Anastassia Zabrodskaja.

\section{Kasutatud kirjandus}

Barber, M., \& Mourshed, M. (2007). Kuidas maailma tulemuslikumad haridussüsteemid on jõudnud tippu. McKinsey \& Kompanii. Külastatud aadressil www.hm.ee/index.php?popup=download\&id=7878.

Bertaux, P., Coonan, C. M., Frigols-Martín, M. J., \& Mehisto, P. (2010). The CLIL teacher's competences grid. CLIL Cascade Network.

Retrieved from http://lendtrento.eu/convegno/files/mehisto.pdf.

Brophy, J. (2004). Motivating students to learn (2nd ed.). Mahwah, London: Lawrence Erlbaum Associates.

Brudan, A. (2010). Rediscovering performance management: Systems, learning and integration. Measuring Business Excellence, 14(1), 109-123.

doi: http://dx.doi.org/10.1108/13683041011027490

Brüning, C. I., \& Purrmann, M.-S. (2014). CLIL pedagogy in Europe: CLIL teacher education in Germany. In J. de Martínez Agudo (Ed.), English as a foreign language teacher education: Current perspectives and challenges (pp. 315-338). Amsterdam, New York: Editions Rodopi P.V.

Cohen, D. K., Peterson, P. L., Wilson, S., Ball, D., Putnam, R., Prawat, R., Wiemars, N. (1990). Effects of state-level reform of elementary school mathematics curriculum on classroom practice. NCRTE Research Rep. 90-14. East Lansing: Center for the Learning and Teaching of Elementary Subjects.

Coyle, D. (2002). Relevance of CLIL to the European Commission's language learning objectives. In D. Marsh (Ed.), CLIL/EMILE - The European dimension: Actions, trends and foresight potential. Public services contract DG EAC (pp. 27-28). Strasbourg: European Commission. 
Coyle, D. (2007). Content and language integrated learning: Towards a connected research agenda for CLIL pedagogies. International Journal of Bilingual Education and Bilingualism, 10(5), 543-562.

Cummins, J. (2000). Language, power \& pedagogy: Bilingual children in the cross-fire. Clevedon: Multilingual Matters.

Dörnyei, Z. (1994). Motivation and motivating in the foreign language classroom. The Modern Language Journal, 78(3), 273-284. doi: http://dx.doi.org/10.1111/j.1540-4781.1994.tb02042.x

Dörnyei, Z. (Ed.) (2001). Motivational strategies in the language classroom. Cambridge: Cambridge University Press. doi: http://dx.doi.org/10.1017/CBO9780511667343

EUCLID project consortium (2011). The CLIL teacher profile. Education and Culture DG.

Euroopa keeleõppe raamdokument: õppimine, õpetamine ja hindamine (2007). Tartu: Haridus- ja Teadusministeerium. Külastatud aadressil https://www.hm.ee/sites/default/files/euroopa_keele6ppe_raamdokument.pdf.

Fullan, M. G., Bennett, B., \& Rolheiser-Bennett, C. (1990). Linking classroom and school improvement. Educational Leadership, 47(8), 13-19.

Gardner, R. C. (2007). Motivation and second language acquisition. Porta Linguarum, $8,9-20$.

Genesee, F., \& Lindholm-Leary, K. (2012). The education of English language learners. In K. Harris, S. Graham, \& T. Urdan (Eds.), APA handbook of educational psychology (pp. 499-526). Washington: APA Books.

Goldenberg, C., \& Sullivan, J. (1994). Making change happen in a language minority school: A search for coherence. NCRCDSLL Educational Practice Reports, 13. Center for Research on Education, Diversity and Excellence, UC Berkeley. Retrieved from http://escholarship.org/uc/item/4sf6j3g4.

Graaff, R. de, Koopman, G.-J., Anikina, Y., \& Westhoff, G. (2007). An observation tool for effective L2 pedagogy in content and language integrated learning (CLIL). International Journal of Bilingual Education and Bilingualism, 10(5), 603-624.

Green, P. (Ed.) (1999). Raise the standard: A practical guide to raising ethnic minority and bilingual pupils' achievement informed by policy and practice in cities across the European Community. Stoke-on-Trent: Trentham Books.

Kitsnik, M. (2014). Õppematerjali mõju gümnaasiumiõpilaste õpimotivatsioonile: „Praktiline eesti keel teise keelena: B2, C1”. Uurimusi keele omandamisest, ópetamisest ja korpustest / Studies in Language Acquisition, Learning \& Corpora, 16, 172-201.

Klaas-Lang, B., Praakli, K., Peedisson, A., \& Lašmanova, A. (2014). Arvamusi ja hinnanguid riigikeele óppe korraldamise kohta vene õppekeelega koolides. Uuringu lõpparuanne. Tartu: Tartu Ülikooli eesti keele (võõrkeelena) osakond. Külastatud aadressil https://dspace.utlib.ee/dspace/bitstream/handle/10062/45121/Arvamusi_ ja_hinnanguid_riigikeele_oppe_korraldamise_kohta.pdf?sequence $=1$.

Krall, I., Sõrmus, E., \& Toomsalu, M. (1997). Kommunikatiivse keeleõppe lühikursus. Tallinn: Eesti Keele Instituut.

Lindholm-Leary, K., \& Borsato, G. (2006). Academic achievement. In F. Genesee, K. Lindholm-Leary, W. Saunders, \& D. Christian (Eds.), Educating English language learners: A synthesis of research evidence (pp. 176-222). Cambridge: Cambridge University Press.

Loogma, K., Ruus, V-R., Talts, L., \& Poom-Valickis, K. (2009). Õpetaja professionaalsus ning tõhusama ópetamis- ja õppimiskeskkonna loomine. OECD rahvusvahelise õpeta- 
mise ja õppimise uuringu TALIS tulemused. Tallinn: Tallinna Ülikooli haridusuuringute keskus. Külastatud aadressil http://dspace.utlib.ee/dspace/bitstream/ handle/10062/40808/Rahv_TALIS.pdf?sequence $=1$.

Marsh, D. (1994). Bilingual education \& content and language integrated learning. International Association for Cross-cultural Communication, Language Teaching in the Member States of the European Union (Lingua). Paris: University of Sorbonne.

Marsh, D. (Ed.) (2002). CLIL/EMILE - The European dimension: Actions, trends and foresight potential. Public services contract DG EAC. Strasbourg: European Commission.

Marsh, D., Mehisto, P., Wolff, D., \& Frigols, M.-J. (2011). European framework for CLIL teacher education. Retrieved from http://www.ecml.at/tabid/277/PublicationID/62/Default.aspx.

Mehisto, P. (2009). Hiliskeelekümblusprogrammi jätkusuutlikkus. Uuringu aruanne. Tallinn. Külastatud aadressil www.hm.ee/index.php?popup=download\&id=9194.

Mehisto, P. (2011). Navigating management and pedagogical complexities in bilingual education: An Estonian case study (Doctoral dissertation). London: University of London.

Mehisto, P., Marsh, D., Frigols, M.-J., Võlli, K., \& Asser, H. (2010). Lõimitud aine- ja keeleõpe. Tallinn: Integratsiooni ja Migratsiooni Sihtasutus Meie Inimesed.

Metslang, H., Kibar, T., Kitsnik, M., Koržel, J., Krall, I., \& Zabrodskaja A. (2013). Kakskeelne õpe vene õppekeelega koolis. Uuringu lõpparuanne. Külastatud aadressil https://www.hm.ee/sites/default/files/lisa_2_uuring_kakskeelne_ope_vene_oppekeelega_koolis_0.pdf.

Navés, T. (2009). Effective content and language integrated learning (CLIL) programmes. In Y. Ruiz de Zarobe \& R. M. Jimenez Catalàn (Eds.), Content and language integrated learning: Evidence from research in Europe (pp. 22-40). Bristol, New York, Ontario: Multilingual Matters.

Nunan, D. (2004). Task-based language teaching. Cambridge: Cambridge University Press. doi: http://dx.doi.org/10.1017/CBO9780511667336

Piirimägi, A., Värä, E., Uustalu, H., Kalakauskas, I., Allik, J., Holm, J., ... Belobrovtsev, V. (2014). Raport vene óppekeelt kasutavate gümnaasiumide õppe tulemuslikkusest eestikeelsele (vähemalt 60\% kohustuslikest kursustest) gümnaasiumióppele üleminekul. Külastatud aadressil https://www.hm.ee/sites/default/files/raport_uleminek_viimane_0.pdf.

Sau-Ek, K., Loogma, K., \& Vainu, V. (2011). Hilise keelekümbluse mõju. Uuringu tulemuste aruanne. Tallinn: Tallinna Ülikooli haridusuuringute keskus.

Seepter, K. (2014). Õpilase vaimse võimekuse ja klassi õpikeskkonna seos akadeemilise edukusega kakskeelsetel ja nendega koos õppivatel eestikeelsetel. Eesti Haridusteaduste Ajakiri, 2(1), 182-216. doi: http://dx.doi.org/10.12697/eha.2014.2.1.08

Türk, K., Haldma, T., Kukemelk, H., Ploom, K., Irs, R., \& Pukkonen, L. (2011). Üldharidus- ja kutsekoolide tulemuslikkus ja seda mõjutavad tegurid. Tartu Ülikool, Haridus- ja Teadusministeerium. Külastatud aadressil https://riigikantselei.ee/sites/ default/files/content-editors/TOF/TOF_uuringud/10_koolitulemusjuhtimine20111.pdf.

Williams, M., \& Burden, R. L. (1997). Psychology for language teachers: A social constructivist approach. Cambridge: Cambridge University Press.

Willis, J. (1996). A framework for task-based learning. Harlow: Longman.

Willis, J. (2008). Six types of task for TBL. British Council, BBC World Service. Retrieved from http://www.teachingenglish.org.uk/article/six-types-task-tbl. 


\title{
The effectiveness of content and language integrated learning at Russian speaking schools: school leaders' views and strategies
}

\author{
Mare Kitsnik $^{\mathrm{a} 1}$, Helena Metslang \\ ${ }^{a}$ Tallinn University, Institute of Estonian Language and Culture \\ ${ }^{b}$ University of Tartu, Institute of Estonian and General Linguistics
}

\section{Summary}

The majority of pupils belonging to national minorities in Estonia speak Russian as their first language and study at schools where Russian is taught. Following Estonian independence in 1991 significant improvements to the official language teaching system have been made. The quality of study materials, teacher training, and the language proficiency level of secondary school graduates have also improved. Despite all this the results of the state language exams are below the levels required to ensure that Russian schools' graduates have equal opportunities in higher education and in society in general. In order to improve the situation, the national educational reform was carried out during the period from 2007 to 2012. Starting from 2011 all pupils entering the $10^{\text {th }}$ form at Russian speaking schools have to learn 60 per cent of the upper secondary school curriculum in the Estonian language.

According to the national curriculum the recommended methodology for the subjects that are taught in Estonian as a second language is content and language integrated learning (CLIL). Considerable efforts have been made at state, municipal and schools level to implement this methodology and the schools have indeed started using Estonian as their language of choice. Many schools already have long-term experiences of teaching several subjects in Estonian. However, the process has not been easy for pupils or schools. In accordance with the national curriculum Estonian has become the obligatory language of instruction only in upper secondary schools. The Estonian bilingual education model is rare in the world context. Models where pupils start studying in a language other than their mother tongue, either in kindergarten or primary school, are more wide-spread. This article highlights the understanding of topical issues such as late starting models based on the Estonian model.

1 Institute of Estonian Language and Culture, Tallinn University, Narva mnt 29, 10120 Tallinn, Estonia; marekitsnik@gmail.com 
In this article we give an overview of school leaders' experience and views on the above-mentioned reforms and introduce some of the results of the study Bilingual study in Russian-medium schools (Metslang et al., 2013). We conducted 12 interviews with headmasters and head teachers at 6 schools. On the basis of these interviews we describe the school leaders' main concerns and strategies implementing this new language programme. We focused on the aspects that are directly related to the lesson situations to studying and teaching in language lessons and content subjects taught in Estonian. In order to provide context and to help the reader understand the school managers' position we compared the results of the interviews with other research results obtained during the study ( 77 lesson observations in forms 9 to12, content subject, teacher, pupil, language teacher questionnaires and focus group interviews with the same groups). The main sample included 8 schools, the number and location of which reflected the national distribution of the schools where Russian was the main language.

All the interviewed school leaders had generally a positive attitude towards using Estonian as the first language and they supported its potential in preparing the pupils to succeed in life. This result is important because educational reform depends largely on the attitude of school leaders. However, school leaders are critical about the details on how the new programme has been implemented - for example, about the proportion of Estonian used in teaching. They are aware that there are several problems that hinder pupils' academic success within the framework of the new programme i.e. insufficient Estonian and study skills of the pupils entering upper secondary school, their low motivation to learn Estonian, the lack of teachers and study materials suitable for CLIL.

When discussing how they lead and support the new programme the school leaders reported that they react on day to day basis to the emerging needs and learn rather through practical application. However, they did not report systematic use of leadership or management tools as a daily way to influence the success of the programme, for instance using the school's strategic development or work plans for enhancing CLIL. The school heads did not have a good understanding of the CLIL methodology and the activities needed for its implementation. They did not have a CLIL teacher training strategy in place and (as lesson observations revealed) there is no evidence that the CLIL methodology taught at in-service training courses is put into practice in everyday teaching - there is a lack of monitoring and support in this area. Currently there is scope for development in organising effective co-operation between teachers and other stakeholders. 
It appeared during interviews that the school leaders did not have a good understanding of the reasons that influenced the effectiveness of Estonian as a second language, its teaching and the pupils' motivation to study Estonian. As pupils' Estonian skills are key to the programme's success, school leaders need to be aware of how to manage these factors, how to ensure that good quality methodology is being used and that language lessons support the study of other subjects in Estonian (the latter depends also on national requirements, and currently the national curriculum does not include the teaching of academic Estonian).

Keywords: Estonian, language learning, bilingual education, content and language integrated learning, methodology, management 